\title{
Thrombophilic risk factors in women with recurrent abortion
}

\section{Tekrarlayan düşük yapan kadınlarda trombofilik risk faktörleri}

\author{
Osman Yokuş ${ }^{1}$, Özlem Şahin Balçık ${ }^{2}$, Murat Albayrak ${ }^{3}$, Funda Ceran ${ }^{4}$ Mesude Yılmaz ${ }^{4}$, \\ Simten Dağdaş̧, Gülsüm Özet ${ }^{4}$ \\ ${ }^{1}$ Okmeydanı Education and Research Hospital, Department of Hematology, Istanbul, Turkey \\ ${ }^{2}$ Fatih University Medical School, Department of Hematology, Ankara, Turkey \\ ${ }^{3}$ Dışkapı Yıldırım Beyazıt Education and Research Hospital, Department of Hematology, Ankara, Turkey \\ ${ }^{4}$ Ankara Numune Education and Research Hospital, Department of Hematology, Ankara, Turkey
}

\section{ABSTRACT}

Objectives: The aim of this study was to determine the thrombophilic risk factors and their frequency among women with history of recurrent abortion and a detected thrombophilic defect.

Materials and methods: In this study, 41 women with history of recurrent abortion, who have one or more detected thrombophilic defects including protein $\mathrm{S}$, protein $\mathrm{C}$, antithrombin deficiency, activated protein $\mathrm{C}$ resistance (APC-R), factor V Leiden (FVL), prothrombin G 20210A (PTG), methylenetetrahydrofolate reductase (MTHFR) C677 T gene mutation, antiphospholipid antibodies and elevated levels of factor VIII were retrospectively investigated.

Results: The most common detected thrombophilia defect $(53.7 \%)$ was MTHFR gene mutation. While 22 of 41 patients $(53.7 \%)$ had more than one concomitant defect, 20 of them had two concomitant defects and the remaining had three defects.

Conclusion: MTHFR gene mutation, alone and/or with, concurrent thrombophilic defects was the most frequent factor for hereditary thrombophilia among our patients with a history of recurrent abortion. J Clin Exp Invest 2010; 1(3): 168-172

Key words: thrombophilia; clinical thrombophilia, recurrent abortion, factor $\mathrm{V}$ Leiden gene mutation, actived protein-C resistance, methylenetetrahydrofolate reductase gene mutation, prothrombin G20210A gene mutation, protein $\mathrm{C}$ deficiency, protein $\mathrm{S}$ deficiency; anticardiolipin antibody, lupus anticoagulant

\section{ÖZET}

Amaç: Bu çalışmada, tekrarlayan düşük nedeni ile hematoloji polikliniğine başvuran ve en az bir trombofilik defekt saptanan kadınlarda trombofilik risk faktörleri ve sıkı̆̆ını değerlendirmek amaçlanmıştır.

Gereç ve yöntem: Bir ya da daha fazla trombofilik defekt (protein $\mathrm{S}$ eksikliği, protein $\mathrm{C}$ eksikliği, antitrombin, aktive protein $\mathrm{C}$ direnci (APC-R), faktör V Leiden ( $F V L$ ), protrombin G 20210A (PTG), metilentetrahidrofolat redüktaz (MTHFR C677 T) gen mutasyonları, antifosfolipid antikorları (antikardiyolipin antikoru lgM ve lgG, lupus antikoagülanı) varlığı ve Faktör VIII yüksekliği) ve tekrarlayan abortus öyküsü olan 41 olgu geriye dönük olarak araştırıldı.

Bulgular: En sık saptanan trombofilik defekt \%53.7 MTHFR 677T mutasyonu idi. Kırk bir hastanın 22'si (\%53.7) (n:22; 20 ikili, 2 üçlü defekt) birden fazla defekti aynı anda birlikte taşımaktayken, 20'si aynı anda iki, geri kalanı üçlü defekte sahipti.

Sonuç: Hasta grubumuzda MTHFR gen mutasyonu tek ve/veya diğer trombofilik faktörlerle kombine olarak, tekrarlayan abortuslu hastalarda en sık rastlanan herediter trombofili etkeni olarak saptandı. Klin Den Ar Derg 2010; 1(3): 168-172

Anahtar kelimeler: trombofili; klinik trombofili, tekrarlayan abortus, factör $\mathrm{V}$ Leiden gene mutasyonu, aktive protein-C direnci, metilentetrahidrofolat redüktaz gen mutasyonu, protrombin G20210A gen mutasyonu, protein C eksikliği, protein S eksikliği, antikardiolipin antikor, lupus antikoagülanı 


\section{INTRODUCTION}

Thrombophilia is defined as a predisposition to thrombosis because of disturbances in hemostatic mechanisms. It may originate from hereditary or acquired causes. ${ }^{1}$ Disturbances of anticoagulant mechanisms that occur during pregnancy can cause thrombophilia. This can result in placental insufficiency and abortus..$^{2-8}$

Recurrent abortion is the condition that defined as three or more spontaneous consecutive miscarriages at a gestational age of 20 weeks or less. The frequency of recurrent abortion is about $0.5-1 \%$ per 100 pregnancy. ${ }^{9}$ While the females having pregnancy complications were detected to have thrombophilic defects in a ratio of $49-65 \%$, this frequency was found about $18-22 \%$ in normal pregnancies. This make people think that complication risk increases by 3-8 fold, based on thrombophilia. . $^{3,10,11}$

Increased early and late miscarriage risk for females with thrombophilic defects has been reported. ${ }^{12}$ Thrombophilia screening tests should be done in cases with venous thromboembolism occurred during pregnancy or puerperium, first and second trimester miscarriages and intrauterine fetal death, however, routine screening is not advised for all pregnancies. ${ }^{13}$ It is well known that the frequency of thrombophilic defects would differ among distinct societies.

The aim of this study was to determine the thrombophilic risk factors and their frequency in women that presented to the hematology outpatient clinics with recurrent abortion history and at least one detected thrombophilic defect.

\section{MATERIALS AND METHODS}

Forty one women that presented with a history of recurrent abortus and found to have at least one thrombophilic defect during examination were evaluated retrospectively. Patients admitted with spontaneous abortion without any thrombophilic risk factor were not included in the study. Demographic and clinical characteristics of the study group are summarized in Table 1.Written informed consent was obtained from all patients before drawing the blood samples. The study was carried out in accordance with the Helsinki Declaration.
Patients with oral contraceptive usage and hormone replacement therapy, with prior surgical intervention history of recent date and patients with a diagnosis of myeloproliferative disease, paroxysmal nocturnal hemoglobinuria $(\mathrm{PNH})$, diabetes mellitus, dyslipidemia, chronic liver disease, malignancy, vasculitis, collagenous tissue disease and central venous catheter thrombosis were excluded from the study. Laboratory tests related to thrombophilia were performed at least 3 months after a thrombotic event, at least 15 days after discontinuation of heparin therapy or its derivatives and at least 4 weeks after discontinuation of warfarine derivatives. Positive results were repeated at least once again. No the patients were pregnant at the time of laboratory studies.

In this study, we evaluate antithrombin (AT) activity, protein $\mathrm{C}$ (PC) activity, total and free protein $\mathrm{S}$ (PS) antigen and activity, activated protein $\mathrm{C}$ resistance, factor V Leiden (FVL) G1691A gene mutation, prothrombin 20210A (PTG) gene mutation, methylenetetrahydrofolate reductase (MTHFR) C677T gene mutation, factor VIII (F VIII) levels and antiphospholipid antibodies including APA, anticardiolipin antibodies (ACA) IgG and ACA IgM and finally lupus anticoagulant. Commercial PCR kits (MTHFR LC PCR, QIAGEN) were used to investigate MTHFR C677T gene mutations. Prothrombin G20210A gene mutations and FVL mutations were also detected by using commercial kits (Roche Diagnostics). We used "LightCycler 1.5" ROCHE" real time PCR device in our study. Twelve-hour fasting needed for venous blood sampling and citrated blood specimens were centrifuged at $1500 \mathrm{x} g$ for 15 minutes to measure AT, PC, PS, APC-R, LA, FVIII levels. Citrated samples were stored at -20C while waiting. PC activity, PS activity, AT activity and FVIII levels were examined by commercial kits (Dade Behring) and APC-R was assessed by a Dade Behring proC global kit. BCS instrument (DadeBehring) was used for test analyses. Cut-off values were determined by a laboratory reference range study on 40 healthy individuals and the following ranges were accepted to be normal: $70-140 \%$ for protein $\mathrm{C}$ activity, $58-127 \%$ for protein $\mathrm{S}$ activity, $75-125 \%$ for AT activity and $70-150 \%$ for FVIII activity. Patients with high levels of APTT were examined by LA-sensitive aPTT reagent PTT-LA (Diagnostica Stago) test. Presence of heparin, dysfibrinogenemia, factor inhibitors, intrinsic pathway 
factor deficiencies were excluded. The plasma clotting time increases in the presence of LA. Difference of 8 seconds between the two clotting times was accepted to be positive for LA. Diagnostica Stago STart 4 Hemostasis Analyzer (Diagnostica Stago, France) was used for these analyses. Commercial Intec cardiolipin IgM and IgG 1 ELISA kits were used to detect ACA IgM and ACA IgG levels on a Biomaster instrument. Values less than 2.0 PL-U/ml were accepted to be normal for ACA IgM and ACA IgG. Values more than $12 \mathrm{PL}-\mathrm{U} / \mathrm{ml}$ for at least two separate measurements was considered to be positive.

\section{Statistical analyses}

SPSS 13.0 for Windows Statistical Software Package was used to analyze the data. The descriptive statistics including mean \pm standard deviation were used for continuous variables and number and percents of categorical variables.

\section{RESULTS}

A thrombosis history was documented in $17.1 \%$ of the patients $(n=7)$ before the study. Family history for thrombosis was positive for only one patient. The most frequently detected thrombophilic defect was MTHFR 677T gene mutation with a percentage of $\% 53.7$ ( $\mathrm{n}=22 ; 15$ heterozygote, 7 homozygote). This ratio was followed by FVL gene mutation with a percentage of $39 \%(n=16 ; 14$ heterozygote, 2 homozygote) and PS deficiency with a percentage of $19.5 \%(\mathrm{n}=8)$. The ratio of patients having more than one concurrent defects $(n=22)$ was $53.7 \% ; 20$ of them had two, while the remaining had 3 concurrent defects. Detected concomitant thrombophilic defects in our study group presented with a history of recurrent abortion and their frequency are shown in the Table 1.

\section{DISCUSSION}

Hereditary thrombophilia may cause infarcts secondary to placental vascular thrombosis that results in recurrent miscarriages and intrauterine fetal death. ${ }^{14}$ In our study, as well as PC, PS, AT activity deficiency, FVL gene mutation, APC-R, PTG and MTHFR gene mutation; the presence of anticardiolipin antibodies and LA tests were also done for hereditary thrombophilia screening. Homocysteine levels were ruled out of the study because it is affected by too many acquired factors and nutritional status of the patient.

Existing studies showed that FVL gene and PTG mutations were the most frequent risk factors among patients with recurrent fetal loss. Investigation of these two mutations primarily in patients with recurrent miscarriages of unknown origin have been recommended. Also it was reported that FVL gene mutation and PT gene mutation were the most frequent defects that may be together. The ratio for concomitance of two defects was found as $17.6 \%$ in our study and this ratio was higher than the previously reported ratios for normal population. ${ }^{15}$

In a previous study, it was shown that concomitance of two or more defects together and/or homozygosity of the mutation effects pregnancy more unfavorably, compared to the presence of single hereditary thrombophilic factor. ${ }^{16}$ Among our patients, the most frequently observed concomitant defects were MTHFR and FVL gene mutation. Whereas double defects ratio was found to be $48.8 \%$, the total ratio for combined defects was found as $53.7 \%$ in our study. Increase of this ratio may be based on the fact that the patients with at least one thrombophilic defect were included in the study. Occurrence of more than one defect concomitantly for approximately half of the patients in our study is compatible with this literature data. The results of investigations about whether MTHFR gene mutation increases the risk for recurrent abortion is still controversial. ${ }^{17,18}$ Whereas the ratio of MTHFR C677T gene mutation among patients with a history of recurrent abortion has been found as $30 \%$, while it was $7 \%$ for control group. ${ }^{19}$ This data is in concordance with the findings of our study that indicate high levels of MTHFR gene mutation. In that study, it was shown that MTHFR gene mutation was related to early and late complications of pregnancy. ${ }^{19}$

Limitation of our study was the lack of control group consisting of healthy subjects had the history of normal pregnancy and the patients presented with recurrent abortus without thrombophilic risk factor.

In conclusion, MTHFR gene mutation may be the most frequent hereditary thrombophilic factor among patients with a history of recurrent abortion in women. It can be suggested that the patients who are presented to hematology outpatient clinics in order to be examined about the etiology of recur- 
rent abortion, must be investigated primarily about anticardiolipin antibodies (and/or Lupus anticoaguthe most frequent thrombophilic defects-MTHFR lant) as it may cause several complications during and FVL gene mutations- and about the presence of pregnancy.

Table 1. Demographic and clinical characteristics of the study group

\begin{tabular}{ll}
\hline Patients $(n)$ & 41 \\
Age, median range (min-max)* years & $31(20-45)$ \\
Live births, median range $(\min -\max )^{*}(\mathrm{n})$ & $1(0-5)$ \\
Miscarriages, median range (min-max)* $(n)$ & $3(3-14)$ \\
Other pregnancy complications $(n=4)$ & preeclampsia $(n=3)$, intrauterine fetal death $(n=1)$ \\
Previous treatment modalities & warfarin $(n=4$, for previous IS and PE) \\
Thrombosis history $(n=7)$ & IS $(n=3)$, DVT $(n=3), P E(n=1)$ \\
APS & $n=3$
\end{tabular}

*: minimum-maximum, IS: ischemic stroke, PE: pulmonary embolism, DVT: deep venous thromboses, APS: antiphospholipid syndrome

Table 2. The frequency of single and concomitant thrombophilic defects detected in cases with recurrent abortion

\begin{tabular}{|c|c|}
\hline \multirow{11}{*}{ Thrombophilic defects $(n=41)$} & MTHFR: $53.7 \%(n=22 ; 15$ heterozygotes, 7 homozygotes $)$ \\
\hline & FVL: $39 \%(n=16 ; 14$ heterozygotes, 2 homozygotes) \\
\hline & PS: $19.5 \%(n=8)$ \\
\hline & APA: $14.6 \%(n=6)$ \\
\hline & PTG: $12.2 \%$ ( $n=5 ; 3$ heterozygotes, 2 homozygotes) \\
\hline & FVIII: $9.8 \%(n=4)$ \\
\hline & PC: $4.9 \%(n=2)$ \\
\hline & A-PCR: $4.9 \%(n=2)$ \\
\hline & Single thrombophilic defect: $19(46.3 \%)$ \\
\hline & Two defects: 20 (48.8\%) \\
\hline & Three defects: 2 (4.9\%) \\
\hline \multicolumn{2}{|l|}{ Concomitant thrombophilic defects (\%) } \\
\hline The most common is MTHFR: $31.7(n=13)$ & MTHFR+PS+APA $(n=1), M T H F R+P S+F V L(n=1)$ \\
\hline Second common is FVL: $26.8(n=11)$ & MTHFR+FVL $(n=4), M T H F R+F V I I I ~(n=2), M T H F R+A P A(n=2), M T H F R+P S(n=3)$, \\
\hline Third common is PS: $17(n=7)$ & $\begin{array}{l}\text { PTG+FVL(n:4), PTG+FVIII }(n=1), P C+F V I I I(n=1), P C+F V L(n=1), P S+F V L(n=1) \\
P S+A P C-R(n=1)\end{array}$ \\
\hline
\end{tabular}

FVL: Factor V Leiden G1691A gene mutation; MTHFR: 5,10-methylenetetrahydrofolate reductase C677T gene mutation; PTG: Prothrombin G20210A gene mutation; PC: protein C deficiency; PS:protein S deficiency; FVIII: Elevated factor VIII levels; APA: Antiphospholipid antibody (anticardiolipin antibody IgG , IgM and lupus anticoagulant), APC-R: Actived protein-C resistance without FVL gene mutation 


\section{REFERENCES}

1. Friedman KD, Rodgers GM. Thrombosis and Antithrombotic Therapy. In: Greer JP, Foerster J, Lukens J, Rodgers G, Paraskevas F, Glader B (Editors). Wintrobe's Clinical Hematology. 11th Edition, Philadelphia: Lippincott Williams \& Wilkins, 2004: 1713-1728.

2. Geyman JP, Oliver LM, Sullivan SD. Expectant, medical, or surgical treatment of spontaneous abortion in first trimester of pregnancy? A pooled quantitative literature evaluation. J Am Board Fam Pract 1999;12:55-64.

3. Reznikoff-Etiévan MF, Cayol V, Carbonne B, et al. Factor V Leiden and G20210A prothrombin mutations are risk factors for very early recurrent miscarriage. BJOG 2001;108:1251-4.

4. de Vries JI, Dekker GA, Huijgens PC, et al. Hyperhomocysteinaemia and protein $\mathrm{S}$ deficiency in complicated pregnancies. Br J Obstet Gynaecol 1997;104:1248-54.

5. Dekker GA, de Vries JI, Doelitzsch PM, et al. Underlying disorders associated with severe early-onset preeclampsia. Am J Obstet Gynecol 1995;173:1042-8.

6. Wouters MG, Boers GH, Blom HJ, et al. Hyperhomocysteinemia: a risk factor in women with unexplained recurrent early pregnancy loss. Fertil Steril 1993;60:820-5.

7. Kupferminc MJ, Eldor A, Steinman N, et al. Increased frequency of genetic thrombophilia in women with complications of pregnancy. N Engl J Med 1999;340:9-13.

8. van Pampus MG, Dekker GA, Wolf H, et al. High prevalence of hemostatic abnormalities in women with a history of severe preeclampsia. Am J Obstet Gynecol 1999;180:114650 .

9. Clark DA, Lea RG, Podor T, et al. Cytokines determining the success or failure of pregnancy. Ann NY Acad Sci 1991; 626: 524-36.
10. Salvagno GL, Lippi G, Franchini M, et al. The cost-benefit ratio of screening pregnant women for thrombophilia. Blood Transfus 2007;5:189-203.

11. Brenner B. Inherited thrombophilia and pregnancy loss. Thromb Haemost 1999;82:634-40.

12. Tripodi A. Issues concerning the laboratory investigation of inherited thrombophilia. Mol Diagn 2005;9:181-6.

13. Robertson L, Wu O, Langhorne P, et al. Thrombosis: Risk and economic assessment of thrombophilia screening (TREATS) study. Thrombophilia in pregnancy: a systematic review. Br J Haematol 2006;132:171-96.

14. Greer IA. Venous thromboembolism and anticoagulant therapy in pregnancy. Gend Med. 2005;2 Suppl A:S10-17.

15. Santoro R, Iannaccaro P, Sottilotta G. Prothrombotic gene mutations in women with recurrent abortions and intrauterine fetal death. Minerva Ginecol 2005;57:447-50.

16. Coulam CB, Jeyendran RS, Fishel LA, et al. Multiple thrombophilic gene mutations rather than specific gene mutations are risk factors for recurrent miscarriage. Am J Reprod Immunol 2006;55:360-8.

17. Makino A, Nakanishi T, Sugiura-Ogasawara M, et al. No association of C677T methylenetetrahydrofolate reductase and an endothelial nitric oxide synthase polymorphism with recurrent pregnancy loss. Am J Reprod Immunol 2004;52:60-6.

18. Foka ZJ, Lambropoulos AF, Saravelos H, et al. Factor V leiden and prothrombin G20210A mutations, but not methylenetetrahydrofolate reductase C677T, are associated with recurrent miscarriages. Hum Reprod 2000;15:458-62.

19. De Stefano V, Casorelli I, Rossi E, et al. Interaction between hyperhomocysteinemia and inherited thrombophilic factors in venous thromboembolism. Semin Thromb Hemost 2000;26:305-11. 